\title{
Electrical impedance measurement on plants: a review with some insights to other fields
}

\author{
Ildikó Jócsák (iD · György Végvári · Eszter Vozáry
}

Received: 20 June 2018/Accepted: 7 August 2019/Published online: 30 August 2019

(C) The Author(s) 2019

\begin{abstract}
Electrical impedance spectroscopy (EIS) is a useful tool for the investigation of the structural characteristics of solid materials and also biological tissues. The structural changes in plant or animal tissues reflect the physiological state of the organism. Electrical impedance measurement seems to be applicable both for analytical and research laboratories, since once a stress or a quality trait is correlated with an impedance parameter the method is quick and safe for further analysis of great number of samples. This work attempted to explore the current state of literature in terms of the application of EIS that has already been done on animal and plant tissues, and more specifically searching for the possibility of wider future applicability in plant stress detection.
\end{abstract}

Keywords Electrical impedance $\cdot$ Structural changes $\cdot$ Plant sciences $\cdot$ Stress detection

I. Jócsák (囚) · G. Végvári

Faculty of Agricultural and Environmental Sciences, Institute of Physiology, Biochemistry and Animal Health, University of Kaposvár, Guba Sándor. Str. 40,

Kaposvár 7400, Hungary

e-mail: jocsak.ildiko@ke.hu

E. Vozáry

Department of Physics and Automatics, Szent István

University, Str. 14-16, Budapest 1118, Hungary

\section{Introduction}

It is a constant concern of researchers in plant sciences (including plant physiology, plant stress physiology, agriculture, food sciences etc.) to find new possibilities for detecting changes of the investigated tissue or plant organ in a more effective and more sensitive way than the ever current state of art. The directions lead towards enhanced sensitivity that enables to determine tissue or organ metabolic and/or structural alterations in plants before the occurrence of visible symptoms. Another important and desirable criterion is that the measurement should be quick, giving the advantage of investigating a large number of samples in a relatively short time, since the phenology of plants may change rapidly, whether one tries to characterize seedlings or a plant stand for example.

Electrical impedance measurement (complex resistance in the presence of alternating current) is a useful tool for the investigation of the structural characteristics of solid materials and biological tissues, the changes of the latter reflect the physiological state of the tissue itself (Hayden et al. 1968). Because of the passive electrical properties, plant tissue impedance is related to cellular ionic content, membrane structures (Privé and Zhang 1996) and viscosity. This opens the possibility to many scientific fields of plant investigation to apply electrical impedance measurement in basic and applied research as well. 
This work attempts to explore the current state of literature in terms of the application of electrical impedance measurement (EIS) that has already been done on animal and plant tissues, and more specifically searching for the possibility of wider future applicability in plant stress detection.

\section{Theory of electrical impedance}

EIS of the lower frequency ranges $(10 \mathrm{~Hz}-1 \mathrm{MHz})$ has been applied extensively in medical science and, in several cases, in plant science as well (Grimnes and Martinsen 2000).

Electrical conduction in biological tissues is due to the presence of ions (Pething and Kell 1987). The current is therefore related to the ionic content and ionic mobility of the particular tissue (Dean et al. 2008). Cellular components and their structure together determine the electrical properties of tissues in various frequency ranges. Therefore, if there is a difference in tissue structure, it will initiate characteristic impedance spectra.

According to the explanation of Dean et al. (2008), electrical impedance of biological tissues is a complex value with resistance and capacitance and it depends on the applied frequency. The real part of the impedance is associated with resistive pathways across the tissues, the imaginary part of the tissue is associated with capacitive pathways, such as membrane structures. The real part is large at low frequencies and the imaginary part becomes more dominant at higher frequencies. At very high frequencies current does not flow, but only moves back and forth between membrane surfaces and the current is limited by the small resistance of the membranes (Dean et al. 2008). In a frequency ranges $(10 \mathrm{~Hz}-$ $1 \mathrm{MHz}$ ), EIS of biological tissues presents a $\beta$ dispersion band associated with membrane structures and is sensitive to their integrity and functionality (Kuang and Nelson 1998; Martinsen et al. 2002). It has been shown through several examples that bioelectric measurements help to understand certain physiological phenomena, since, for example, the application of microelectrodes elucidated some issues of membrane transport (Shabala et al. 2006). EIS is widely applied in the field of biomedical diagnostics and in plant, crop and food sciences as well. The integration of microelectronic and microfluidic techniques, impedance is applicable to nearly all aspects of biology, including living cell counting and analysis, cell biology research, cancer research, drug screening, and food and environmental safety monitoring $(\mathrm{Xu}$ et al. 2016). Before the exploration of the current state of literature in terms of plant-related applications, it is worth mentioning some of its use in material and life sciences.

\section{Applications of electrical impedance in material and life sciences}

In general, EIS can be used for identifying and following detectable cellular responses, ex vivo, in vivo and in vitro (McRae et al. 1999; Zou and Guo 2003; Wang et al. 2005) to take advantage of this prognostic information, especially because, by far, EIS is the only non-invasive technique that gives information on a wide frequency range (Dean et al. 2008).

An investigation (Chilcott et al. 2002) dealing with characterization of conducting, metal-coated membranes by EIS showed sensitivity to variations in values for several of their model parameters that quantify membrane performance characteristics, such as porosity, fouling, surface integrity and roughness. The conductance of the system at lower frequencies was sensitive to variations in membrane porosity, while the high frequency conductance of the membrane in situ is sensitive to the concentration of the solution. They concluded that low frequency measurements reflect the properties of the membrane alone, whereas high frequency measurements reflect those of the membrane and the solution (Chilcott et al. 2002).

Tissue electrical impedance depends on the structure of the investigated tissue and can be used to differentiate between the normal and the altered status of, for example, cancerous tissues in a variety of organs, including breast, cervix, skin, bladder and prostate (Halter et al. 2007). Halter et al. (2008) investigated prostatic adenocarcinoma, benign prostatic hyperplasia, nonhyperplastic glandular tissue and stroma with EIS and found significant conductivity differences between cancer and stroma at all frequencies and significant permittivity differences between cancer and benign prostatic hyperplasia at frequencies greater than $92 \mathrm{kHz}$. 
It was used to study the malignant and normal breast tissues and the state of organs. The impedance data were used to characterize tissues and their changes during ischemia. (Dean et al. 2008).

In vivo analysis of cell growth was first carried out by Sotoyama et al. (1998). They developed a multifunctional microelectrode (MME) system and applied to the in vivo analysis of electrical impedance of cell membranes of tobacco cultured cells (line BY-2). They analysed the cell membrane in contact with the external medium and an intercellular membrane according to the linear circuit models composed of ohmic resistances and capacitances. This attempt was fruitful with certain limitations: the position of the tip of MME is significant, whether it is in the vacuole or in the cytosol, should be clarified in understanding the experimental results. Furthermore, the cell wall is considered to be a slight barrier to the permeation of ions. Once these clarifications are done, the measured value characterizes cell membrane itself (Sotoyama et al. 1998).

A wild type of yeast (Saccharomyces cerevisiae) was used in a study dealing with online monitoring of cell growth by impedance spectroscopy in order to estimate cell concentration. First Soley et al. (2005) experimentally characterized the main variables of the impedance measurement as a function of the yeast culture, then determined the conditions that suited to test its performance along a growth curve. The impedance measurements obtained with an ex situ flow-through system during a batch growth of S. cerevisiae were highly comparable to the results of optical density and dry weight measurements (Soley et al. 2005).

Also, dynamic monitoring of cell growth is possible with EIS, since cell impedance can be characterized by the cell index (CI) values $\left[\left(Z_{i}-Z_{0}\right) \Omega / 15 \Omega\right.$, where $Z_{0}$ is the background resistance and $\mathrm{Z}_{\mathrm{i}}$ is the individual time point resistance] and the normalized cell index was determined as the $\mathrm{CI}_{\mathrm{ti}}$ at a certain time point divided by the $\mathrm{CI}_{\text {nml_time }}$ at the normalization time point (nml_time) (Kuo et al. 2010).

Bai and Prinz (2011) investigated the electrochemical characteristics of the plasma membranes of single cells and organelles. Silicon fabrication technology was used to produce a metal ultra-microelectrode (UME). Furthermore, the UME was characterized in a cell medium using electrochemical impedance spectroscopy. A single rat fibroblast cell, or chloroplast purified from Peperomia metallica leaves, was immobilized by a micropipette after which the UME was inserted into its cytosolic space through cell membrane using a piezo actuator. An in vivo EIS measurement between the UME and the counter electrode outside of a single cell was taken. Then the measurements were analyzed using equivalent circuits in order to estimate the membrane impedance of a single cell (Bai and Prinz 2011).

Paredes et al. (2014) also investigated the real time growth of microbial cultures and found that capacitance and resistance are related to surface coating and conductivity changes in few hours post-infection, also that biological coating cause variations in capacitance, up to $60 \%$, while metabolic activity affects resistance giving a variation up to $15 \%$. Fitting analysis has confirmed experimental results showing also the effect of the dead/alive ratio.

\section{Plant electrical impedance: approaching models}

The structure of solid materials has been tested with EIS for decades. Several models have been constructed for the measured values in order to simplify the evaluation. In medical diagnostics, EIS seems to be applicable based on structural difference of tissues that led plant scientists to widen the applications of EIS even more (MacDonald 1992). As a result of the investigations, it appeared that plant tissue impedance basically depends on three factors between the frequency range of $10 \mathrm{~Hz}-1 \mathrm{MHz}$ :

- intracellular (symplastic) resistance,

- intercellular (apoplastic or extracellular) resistance and

- impedance of the cell membrane.

From an electrical point of view, the cell membrane behaves as a capacitor, the capacitance of which depends on the frequency (Hayden et al. 1968). The impedance spectra of plant tissues have already been characterized by different models. Amongst the first attempts, one has to mention the Hayden-model (Hayden et al. 1968) that consisted of the resistance of cell wall $\left(\mathrm{R}_{1}\right)$, resistance of cell membrane $\left(\mathrm{R}_{2}\right)$, resistance of the cytoplasm $\left(\mathrm{R}_{3}\right)$, and capacitance of cell membrane (C) (Fig. 1). 


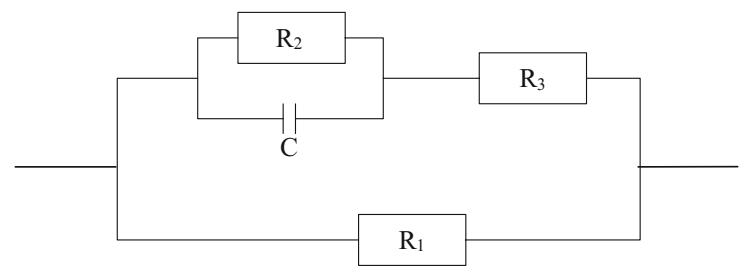

Fig. 1 The Hayden model (Hayden et al. 1968)

The impedance: where $\mathrm{X}$ is the resistance, $\mathrm{X}=1 /$ $\mathrm{C} \omega, \mathrm{C}=$ capacitance of cell membrane, $\omega=$ frequency and $j=\sqrt{-1}$ if $R_{2} \gg R_{3}, R_{1}$, then

$\mathrm{Z}=\frac{\mathrm{R}_{1}^{2} \mathrm{R}_{3}+\mathrm{X}^{2} \mathrm{R}_{1-\mathrm{j}} \mathrm{XR}_{1}\left(\mathrm{R}_{1}-\mathrm{R}_{3}\right)}{\mathrm{R}_{1}^{2}+\mathrm{X}^{2}}$

If the measuring frequency is low and $\omega \rightarrow 0$, then $\mathrm{Z}=\mathrm{R}_{1}$ and if the frequency is high, so $\omega \rightarrow \propto$, then $\mathrm{Z}=\mathrm{R}_{3}$.

At low frequencies, electrical current cannot go through plasma membrane and it is restricted to the apoplast, while at high frequencies the current goes through the symplast (Harker and MainDonald 1994).

The modified Hayden-model (Fig. 2) is a more developed version of the original (Toyoda and Tsenkova 1998), that also takes into account the fact that the impedance of the cell membrane depends on the frequency:

The impedance is given as:

$\mathrm{Z}=\frac{1}{1 / \mathrm{Ra}+1 / \mathrm{Rs}+\mathrm{Zm}}$

That consists of the resistance of the extracellular (apoplastic) space ( $\mathrm{Ra})$, the intracellular (symplastic) (Rs) space and the impedance of cell membrane ( $\mathrm{Zm})$ with a constant $\varphi$ angle. The value of $\mathrm{Zm}$ could be expressed as follows:

$\mathrm{Zm}=\cos \varphi+\mathrm{j} \sin \varphi / \mathrm{Cm} \omega$,

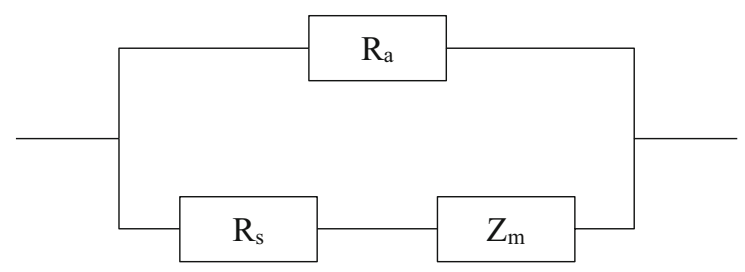

Fig. 2 The modified Hayden-model developed by Toyoda and Tsenkova (1998) where $\mathrm{j}=\sqrt{-1}, \omega=2 \pi \mathrm{f}, \mathrm{f}$ is the frequency of the measuring voltage, and $\mathrm{Cm}$ is the capacity of the cell membrane.

The double-shell model (Fig. 3) considers the resistance of the vacuole in the cytoplasm and the capacitance of the vacuolar membrane (Zhang and Willison 1991):where $R_{1}$ is the resistance of the cell wall and the extracellular space, $R_{2}$ is the resistance of the cytoplasm and the symplasm, $\mathrm{C}_{3}$ is the capacitance of the cell membrane, $\mathrm{R}_{4}$ is the resistance of the vacuole and $\mathrm{C}_{5}$ is the capacitance of the vacuolar membrane.

In EIS, a wide frequency range is used for measuring impedance spectrum (IS), which is comprised of real and imaginary parts, with frequency as an intrinsic variable. An electric circuit model is formulated for the system and the parameters are estimated by means of Complex Nonlinear Least Squares (CNLS) curve fitting. For plant tissues the best fitting results can be obtained with a model consisting of distributed circuit elements (DCE) (Repo and Zhang 1993; Repo et al. 1994, 2000). By using distributed models it is possible to take detailed ISfeatures into account across a wide frequency range, and in that way to obtain mathematically accurate estimates of the model parameters (Repo et al. 2005). The impedance spectra of woody tissues of trees and shrubs also require different models from what is applicable for the tissues of herbaceous plants (Repo and Zhang 1993).

The models mentioned above are convenient to use, since the elements of the circuits represent the resistances and capacitances of different constituents of the tissue. Thus with the help of the models, the measured values can be more easily interpreted (Table 1).

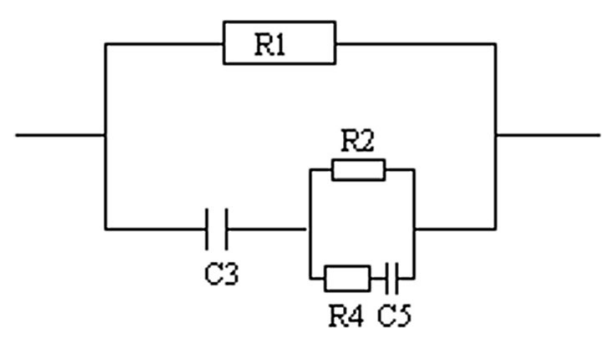

Fig. 3 The double-shell model 
Table 1 Cell culture growth followed by EIS

\begin{tabular}{lll}
\hline Species & Research interest & References \\
\hline Human colon cancer cells & Cell growth & Kuo et al. (2010) \\
Rat Fibroblast Cell/Chloroplast Of Peperomia Metallica & Membrane impedance & Bai and Prinz (2011) \\
Staphylococcus epidermidis & Real time growth of microbial cultures cell & Paredes et al. (2014) \\
Tobacco (Lycopersicon esculentum) & Cell growth & Sotoyama et al. (1998) \\
Yeast (Saccharomyces cerevisiae) & Cell growth & Soley et al. (2005) \\
\hline
\end{tabular}

\section{Plant electrical impedance: applications}

\subsection{Root growth estimation}

In plant sciences some work has been done before for assessing root growth laid on the hypothesis that the capacitance of the root/soil-system reacts with increase of contact surface area between roots and the soil along with the growth of the root (Chloupek 1977; Dalton 1995; Rajkai et al. 2002, 2005). The water-absorbing area of a root is considered to be identical to the zones through which the electric current passes when the tree becomes part of an electric circuit (Nadezhdina and Čermák 2003). The area of root conducting (= absorbing) zones, $\mathrm{S}\left(\mathrm{m}^{2}\right)$ is then calculated from the equation:

$\mathrm{S}=\rho \mathrm{L} / \mathrm{Rz}=\rho \mathrm{LI} / \mathrm{U} * \varepsilon \eta \mathrm{v}$,

where $\rho$ is the resistivity of the woody tissues, which must be estimated separately using a series of thin metallic electrodes and $\mathrm{L}$ is the distance between the tree and the feeding electrode (Nadezhdina and Čermák 2003).

In situ root growth analyses face with several methodological difficulties, which is why a simple, rapid, non-invasive way of its measurement is highly needed (Rajkai et al. 2005). Rajkai et al. (2005) made an investigation on the comparison of pin and clamp (simpler to use under field conditions, but lacking direct contact with sap flow) electrodes using sunflower plants in a pot experiment and found that when the media is water, clamp electrodes are possible to apply, but in other type of media, such as soil at field water capacity, or even capillary saturated soil, pin electrodes better correlated with the root growth. They also found that the best results were obtained when capacitance data was plotted against fresh root mass and not against root length (Table 2).
EIS measurement in a developing root involves several influencing factors, not only the roots themselves, but the soil type and soil moisture content, the spacing and position of electrodes and also the moisture content of the root itself. That is why in the work of Repo et al. (2005) hydroponic culture was used as growth medium in order to simplify the evaluation of the results and to gain knowledge of the change in the root system. With the elimination of the artefacts originating from soil and electrodes, the results indeed gave information only about the root growth. The most important finding was that the sum of the resistances in the distributed electric model decreased with the increase of root mass, according to the model consisting of distributed circuit elements (DCE) (Repo and Zhang 1993; Repo et al. 1994, 2000). Yet, it was not clear that 'which proportion of the change in the resistances is due to the increase of root mass or root surface area and which, if any, is due to the change in stem or stem/solution interface during the growing period' (Repo et al. 2005).

In another study (Hagrey 2007), electric resistivity (DC) was proven to be useful in supporting the geophysical imaging of the root-zone and the trunk. It is thought that electrical properties of a root zone are a consequence of moisture content that enables differentiation between the resistive woody (transporting) and conductive soft (absorbing) roots. That is why it can be successfully used to determine water content and monitor infiltration processes, such as water uptake and sap flow.

\subsection{Frost hardening capability}

Frost hardening is a complex process that enables plants to achieve high frost tolerance, including physiological, physicochemical and chemical changes. The most studied biochemical processes are 
Table 2 Root growth estimation with EIS

\begin{tabular}{lll}
\hline Species & Research interest & References \\
\hline Cork oak (Quercus suber L.) & Geophysical imaging of root-zone & Hagrey (2007) \\
Potato (Solanum tuberosum L.) & Relationship between root electrical capacitance and root size & Chloupek (1972) \\
Sunflower (Helianthus annuus L.) & Comparison of pin and clamp electrodes & Rajkai et al. (2005) \\
Willow (Salix myrsinifolia Salisb) & Simplifying the measurement & Repo et al. (2005) \\
\hline
\end{tabular}

connected to membranes with the increase of unsaturated fatty acids that lowers the temperature-induced phase transition of the membrane. This enables normal membrane permeability even at low temperatures. Other important factors of frost tolerance are the concentration of polar lipids, such as an increase in phospholipids and the state of the cytoplasm (Hietala et al. 1998; Yoshida 1984).

The traditional ways, such as vital staining, ethylene or ethane production- (Chalker-Scott et al. 1989), phenolic- and electrolyte leakage measurements (Anisko and Lindstrom 1995) are either difficult, or expensive, requiring more practical techniques to substitute controlled freeze testing in the future (Repo et al. 1997). Frost results in both quantitative and qualitative changes in cell membranes and cell water-status is the reason why frost hardiness investigations have been done by the method of electrical impedance (Hietala et al. 1998). The work of a Finnish team has been principally focused on the aspects of cold acclimation and frost hardening capability of different species, such as English ryegrass (Lolium perenne) (Repo and Pulli 1996), Azalea (Rhododendron) (Väinölä and Repo 2000), Basket willow (Salix viminalis) (Repo et al. 1997), Scots pine (Pinus sylvestris L.) (Repo et al. 1994), and Silver birch (Betula pendula) (Luoranen et al. 2004) (Table 3).
Distributed model parameters of shoots of five clones of willow (Salix viminalis) were examined with electrical impedance analysis at the end of the growing season during cold acclimation. They found that intracellular resistance correlates with frost hardening in willow (Salix viminalis) especially in the early phase of hardening (Repo et al. 1997) as it was also found by Stout (1988a, b) for alfalfa (Medicago sativa L.) and for birdsfoot trefoil (Lotus corniculatus L.). This correlation is based on the decrease of tissue water content (Sutinen et al. 1992) that decreases ion mobility (Jócsák et al. 2010) and consequently impedes the flow of electric current.

Delayed soil thawing by 7 days delayed the onset of sap flow or totally blocked in Scots pine (Pinus sylvestris L.) that was reflected in the electrical impedance of needles and trunks (Repo et al. 2008). A species-based differentiation between pine and willow was also possible and showed differences between the position of low and high frequency arcs (Repo et al. 1997) that indicated the different tissue structure of the two species. The two main types of Azalea species, i.e. the smaller leaved lepidotes with thinner cuticle, more spongy parenchyma and apoplastic space, and the group of the larger leaved lepidotes with thick cuticule and palisade parenchyma were distinguishable by the same structural principles,
Table 3 Frost hardening capability measurements with EIS

\begin{tabular}{ll}
\hline Species & References \\
\hline Alfalfa (Medicago sativa L.) & Stout (1988a, b) \\
Azalea (Rhododendron) & Väinölä and Repo (2000) \\
Basket willow (Salix viminalis L.) & Repo et al. (1997) \\
Birdsfoot trefoil (Lotus corniculatus L.) & Stout (1988a, b) \\
English ryegrass (Lolium perenne L.) & Repo and Pulli (1996) \\
Scots pine (Pinus sylvestris L.) & Repo et al. (1994, 2008) \\
Silver birch (Betula pendula L.) & Luoranen et al. (2004) \\
Willow (Salix viminalis L.) & Hietala et al. (1998) \\
\hline
\end{tabular}


although the originally-studied cold hardiness evaluation gave positive results only in the case of lepidotes (Väinölä and Repo 2000).

\subsection{Fruit and vegetable quality measurement}

EIS was widely used in post harvest quality measurements of different fruit and vegetable species (Table 4). Weaver and Jackson (1966) successfully correlated the proper harvest date of different peach varieties (Babygold, Elberta, Envoy, Golden Jubilee) with impedance.

Impedance measurements could provide physiological insight to the process of ripening: for apple fruit, $\mathrm{CaCl}_{2}$ infiltration slowers ripening most probably because it maintains a membrane integrity that was possible to monitor with EIS through increased resistance values (Lougheed et al. 1981).

Guo et al. (2007) measured the dielectric properties of three honeydew melon cultivars, grown and harvested to provide a range of maturities over the frequency range from $10 \mathrm{MHz}$ to $1.8 \mathrm{GHz}$ as well as the moisture content and the soluble solids content (SSC). The latter was used as an indicator of sweetness-the quality factor in correlation with the dielectric properties. Although they found high correlation between the SSC and permittivity for both the external surface and internal tissue measurements, SSC prediction from the dielectric properties was not satisfactory (Guo et al. 2007).

Euring et al. (2011) found that normalized electric parameters of decaying apples increased with decay and partial tissue degradation was also detectable. The results did not distinguish between varieties indicating that only robust changes can be measured by the electrical impedance.

Nelson (2005) graphically presented dielectric constant $(\mathrm{k})$ (a number relating the ability of a material to carry alternating current to the ability of vacuum to carry alternating current) and loss-factor [the product of the dissipation factor (D) and the dielectric constant $\left(\varepsilon^{\prime}\right)$ of a dielectric material expressed as: $\left.\varepsilon^{\prime \prime}=\mathrm{D} \varepsilon^{\prime}\right]$ data for apple, avocado, banana, cantaloupe, carrot, cucumber, grape, orange, and potato, showing dielectric constants ranging from values of several hundred at $10 \mathrm{MHz}$ to less than 100 at $1.8 \mathrm{GHz}$ and loss factors on the order of one thousand at $10 \mathrm{MHz}$ to less than 20 at $1.8 \mathrm{GHz}$ at 5 to $65^{\circ} \mathrm{C}$. The dielectric loss factor increased consistently with increasing temperature at frequencies below $1 \mathrm{GHz}$ as well as the dielectric constant. The latter though is decreased with temperature at the higher frequencies $(20$ and $120 \mathrm{MHz})$ when dipolar relaxation appears to control the behaviour, whereas at lower frequencies, ionic

Table 4 Fruit and vegetable quality measurement

\begin{tabular}{lll}
\hline Species & Research interest & References \\
\hline Apple (Malus domestica L.) & Ripening & Lougheed et al. (1981) \\
Apple (Malus domestica L.) & Decay processes & Euring et al. (2011) \\
Apple (Malus domestica L.) & Storage & Vozáry and Horváth (1998), Vozáry et al. \\
& & (1997) \\
Apple (Malus domestica L.) & Thaw freeze maturity-soluble solid & Chalermchat et al. (2010) \\
& content & \\
Banana (Musa $\times$ paradisiaca L.) & Dry matter content estimation & Bera et al. (2016) \\
carrot roots (Daucus carota L.) & boiling & Ando et al. (2016) \\
Durian (Durio zibethinus L.) & Maturity & Kuson and Terdwongworakul (2013) \\
Melon (Cucumis melo L.) & Quality sensing & Harker and MainDonald (1994) \\
Melon (Cucumis melo L. cv. 'Prince & Blanching and freeze-thaw & Sugiyama et al. (1989) \\
melon') & & Nelson (2005) \\
Nectarine (Prunus persica L.) & Ripening & Weaver and Jackson (1966) \\
Peach (Prunus persica L.) & Harvest date estimation & Fuentes et al. (2014) \\
Potato (Solanum tuberosum L.) & Heat treatment & Ando et al. (2014) \\
Potato (Solanum tuberosum L.) & Drying & Imaizumi et al. (2015) \\
Potato (Solanum tuberosum L.) & Hot water treatment estimation & Guo et al. (2007) \\
Various species & Ripening &
\end{tabular}


conduction dominates the dielectric behaviour. The data provide new information that is useful in understanding the dielectric heating behaviour and evaluating dielectric properties of agricultural products for quality sensing (Nelson 2005).

Although there are concerns about the applicability of bioelectric changes as maturity indices of fruits and vegetables (Lougheed et al. 1981), the existence of successful attempts indicates the relevance of EIS in quality assessment.

Impedance parameters are also suitable for detection of fruit ripening. Harker and MainDonald (1994) used EIS for characterizing the intracellular and the extracellular resistances and cell membrane changes during ripening of nectarine (Prunus persica L. Batsch cv Fantasia). They found a cell wall resistance decrease from 7181 to $3342 \Omega$ and this was closely related to the changes in fruit texture. They concluded that this decrease was due to an increased concentration of mobile ions in the cell wall and/or in an increase in cross-section of the cell wall accessible to low frequency current as a consequence of cell wall dissolution and ion leakage. Furthermore, their measurements also indicated most extracellular changes during ripening, since neither high frequency measurement (characterizing intracellular state), nor membrane capacitance showed a pronounced change, only low frequency (extracellular) resistance changed markedly.

Fuentes et al. (2014) evaluated microstructural changes treatments in potato tissue caused by $30 \mathrm{~min}$ heat treatments at room temperature, 30, 40, 50, 60 and $70{ }^{\circ} \mathrm{C}$. The potato samples that were treated by 60 and $70{ }^{\circ} \mathrm{C}$ showed significantly different phase values than those processed at $<50{ }^{\circ} \mathrm{C}$. They attributed these changes to the membrane and cell wall degradation, starch gelatinization, and the collapse of starch granules and found EIS a useful tool for monitoring sequential changes in potato tissue during heating (Fuentes et al. 2014). Ando et al. (2014) measured hot air drying at $50-80{ }^{\circ} \mathrm{C}$ of potato by EIS and analyzed the data with the modified Hayden model (Fig. 2) and the analysis revealed that cell membranes damaged and intracellular fluid leaked out from the cells and found that impedance increased as the drying process proceeded as a consequence of moisture loss. Moisture content analysis showed that at the early stage of drying membrane disruption caused the impedance changes, not the changes of the moisture content (Ando et al. 2014).

Sugiyama et al. (1989) carried out EIS measurements on melon (Cucumis melo L. cv. 'Prince melon') in order to study its applicability for quality evaluation. They detected a marked decrease in the extracellular resistance most probably as a result of an increase of fluidity and lowered selective permeability of the cell membrane.

Vozáry and Horváth (1998), Vozáry et al. (1997) documented that during ripening and storage of apple, its symplastic resistance does not change, but the extracellular resistance also decreases and further drops during storage (Vozáry and Horváth 1998, Vozáry et al. 1997).

Ando et al. (2016) conducted different pre-treatments (blanching and freeze-thaw) before drying of carrot roots (Daucus carota L.) and evaluated the changes of cell membranes, cell wall and pectin methyl-esterase (PME) activity. The cell membrane damage and changes of pectin structure in cell walls was followed by EIS and confirmed by microscopic observation. They concluded that pretreatments made the consecutive drying processes faster, with less energy consumed.

Imaizumi et al. (2015) made potato tuber investigations by treating the tubers with hot water and evaluated the changes of the electrical properties, cell membrane structure and texture. They found that the intactness of membranes was the major parameter that determined the equivalent circuit elements such as intercellular resistance ( $\mathrm{Ri})$, extracellular resistance $(\mathrm{Re})$ and membrane capacitance $(\mathrm{Cm})$. They concluded that the information supplied by EIS is applicable for food processing and post harvest management.

EIS studies showed that the electrical impedance of banana stem tissues is drastically decreased due to boiling, since cell membrane structure disruption, $\alpha$ dispersion and $\beta$-dispersion disappears after boiling (Bera et al. 2016).

EIS was investigated to model the dry matter content of durum using partial least squares regression on the stem and the rind at various stages of maturity. Resistance, reactance and the change in impedance and capacitance was recorded in a range of 1-200 kHz. The reactance of the stem cross section and the capacitance of the rind were found to contribute to the prediction of dry matter content (Kuson and Terdwongworakul 2013). 
The influence of the physiological morphology of apple tissue and the orientation of applied electric field on electro-permeabilization was investigated on different tissue regions under pulse treatment and freezethaw experiment. The dependence of cell shape and orientation on electro-permeabilization was found to be correlated strongly to the orientation of the field applied (Chalermchat et al. 2010).

\subsection{Food quality measurements}

EIS was applicable for the determination of unifloral honeys in order to determine the floral origin of different honeys. Scandurra et al. (2013) presented Cole-cole plots-in which the imaginary part of the impedance is plotted as a function of the real part while changing the test frequency-of different unifloral honeys and concluded an obvious differentiation among various floral honeys and stated that EIS is useful for rapid and easy determination of floral origin without any sample preparation (Table 5).

A study about the differentiation among smoked fish products showed that EIS gave the possibility of the selection by salt- and moisture content, although poor correlations between electrical measurements and the studied physico-chemical parameters were obtained possibly as a consequence of fat interference (Karásková et al. 2011).

The detection of adulteration of food products is of high importance and there is a need for fast and wellcorrelating techniques. The parameters of EIS were found to be useful for the estimation of total soluble solids content (TSS). This could supply the basis for prediction of the TSS content in fruit juices and possible adulteration based on conductivity (Żywica and Banach 2015).

Dairy farms have high concern for milk quality control, most importantly for E. coli. Liua et al. (2015) developed an interdigitated microelectrode sensor for determining bacterial concentration in milk. The measurement based on an electrode-milk interface impedance change due to bacterial metabolism. They determined a parameter: detection time (DT) the time needed for $10 \%$ change of impedance at $10 \mathrm{~Hz}$ that was practical for the prediction of initial bacteria concentration as low as 7 cells $/ \mathrm{mL}$, and the highest concentration of bacteria that they were able to detect was $7 \times 10^{8}$ cells $/ \mathrm{mL}$. The proposed impedance sensor proved to be suitable for determining bacterial contamination and could be used at dairy farms and processing plants (Liua et al. 2015).

Nakonieczna et al. (2016) evaluated the usefulness of the impedance spectroscopy technique in food quality control. They investigated the impedance readings of one and two-component solutions of twelve common food additives and six natural juices, both pure and with additions of selected chemical additives, within the frequency range from $20 \mathrm{~Hz}$ to $2 \mathrm{MHz}$. For the interpretation of data, they constructed different equivalent circuits (EECs). The samples consisted of low solute concentration, thus low capacitances were obtained, and random errors occurred that affected the EEC fitting considerably. This excluded the possibility of a straightforward interpretation of the data (Nakonieczna et al. 2016).

Vozáry et al. (1999) found that during drying of apple slices the symplastic resistance does not change until the moisture content of apple slices decreases to $30 \%$. Below this, it starts increasing and at $5-10 \%$ of moisture content, both apoplastic and symplastic resistances increase by an order of magnitude (Vozáry and Horváth 1998).

\subsection{Crop production}

Besides quality measurements, EIS has also been used in farming practices, estimating, and evaluating certain parameters of crop production, such as water
Table 5 Food quality measurement

\begin{tabular}{lll}
\hline Food type & Parameter & References \\
\hline Fruit juices & Adulteration & Żywica and Banach (2015) \\
Honey & Floral origin & Scandurra et al. (2013) \\
Smoked fish & Salt and moisture content & Karásková et al. (2011) \\
Food products & Soluble soild content & Żywica and Banach (2015) \\
Milk & E. coli content & Liua et al. (2015) \\
Food products & Solute concentration & Nakonieczna et al. (2016) \\
\hline
\end{tabular}


supply, or nutrient deficiency (Table 6). One of its agricultural applications was in order to forecast microclimate conditions and prediction of disease epidemiology for greenhouse crops. A wetness sensor was designed for these purposes (Wei et al. 1995), based on the electrical conductivity of a polymer that made good thermal contact with the surface of different shapes and sizes of tomato fruits. The total wetness period, indicated by the impedance changes agreed well with values that were used to estimate dew point temperatures (Wei et al. 1995).

Optimization and management of water resources are essential in intensive farming, so quantification of water supplies are of high importance as well as the characterization of spatial distribution in the ground. In Beauce (France) electrical resistivity tomography was used to estimate water loss of corn due to infiltration and evapotranspiration of a cultivated soil. The increase in the electrical resistivity due to water extraction corresponds to a typical 2D structure of the ground with resistive features under the corn rows and the $2 \mathrm{D}$ inversion of pseudosections was found to be very efficient for demonstrating the effects of evapotranspiration (Panissod et al. 2001).

Leaf water content is an important factor to show water scarcity in farmland. Zheng et al. (2015) developed a four-electrode method to detect the electrical properties of plants: two current probes of constant alternating current into the sample and two voltage probes measuring the voltage drop between two electrodes. The latter was used to characterize the water content of corn through the changes of electrical properties in different developmental stages and water status was measured. There was a clear negative correlation with all three parameters: dry base water content (DWC), wet base water content (WWC), and relative water content (RWC).
The EIS was attempted to use by Meiqing et al. (2016) for the prediction of phosphorous supply in plants. They analyzed five sets of tomato with different $\mathrm{P}$ source concentrations, measured the electrical impedance within the frequency range of $1 \mathrm{~Hz}-$ $\mathrm{MHz}$ and obtained characteristic frequency bands that had high and positive correlation with plant $\mathrm{P}$ content, since cell membranes were damaged by $\mathrm{P}$ deficiency and that intracellular fluid leaked out of cells. They concluded EIS is a potential tool for phosphorous state evaluation, despite other factors, such as diseases, other nutrients and the water status. (Meiqing et al. 2016).

EIS can be also applied to the detection and diagnosis of plant $\mathrm{K}$ nutrition status however the the environmental sensitivity of this method should be taken into account (Jinyang et al. 2016).

\subsection{Applications of EIS in stress investigation: abiotic and biotic stress detection}

The detection of plant stress has been a major issue in plant physiology in the past few decades. There are many tools in the hands of plant stress physiologists for the detections of environmental stresses.

Classical plant stress research deals with highly accurate methods in order to picture plant state or plant health. Most of them require the grinding of plant tissues, such as chlorophyll content and ratio determination (Arnon 1949), protein content measurement, stress-induced enzyme activity change measurements (Jócsák et al. 2008), etc. In all of these cases, plants are used up for the investigations that have the disadvantage of not having the possibility to follow the stressinduced changes and the different stages of plant stress development (Lichtenthaler 1996), such as the response, the restitution, the end and, possibly, the regeneration phase on the same plant individual. This

Table 6 Crop production

\begin{tabular}{lll}
\hline Species & Research interest & References \\
\hline Corn (Zea mays L.) & Quantification of water supplies & Wei et al. (1995) \\
Corn (Zea mays L.) & Leaf water content & Zheng et al. (2015) \\
Tomato (Lycopersicon esculentum L.) & Phosphorous supply & Meiqing et al. (2016) \\
Tomato (Lycopersicon esculentum L.) & Potassium deficiency & Jinyang et al. (2016) \\
Tomato (Lycopersicon esculentum L.) & Wetness & Panissod et al. (2001) \\
Various species & Environmental factors & Lin et al. (2012) \\
\hline
\end{tabular}


fact adds other possible errors to the investigation. Thus one of the major requirements of plant stress detection is that the method should ideally be noninvasive to the plant.

Harmless stress detecting methods are mostly connected to the investigation of the photosynthetic apparatus, such as the chlorophyll content estimating method using SPAD index (Micskei et al. 2009), photosynthetic activity, stomatal conductance, transpiration, chlorophyll fluorescence induction measurement provides valuable information on the general status of plant health, but some disadvantages of the method cannot be overlooked. The data give information only about certain leaf points (Lichtenthaler 1996) that makes formation of a realistic picture about the plant complicated. This drawback later was overcome by the introduction of fluorescence imaging (Szigeti et al. 1996; Takacs et al. 2000; Tuba et al. 1997) technique, but it still lacks the possibility of in situ measurements especially at the early stage of development.

Lin et al. (2012) demonstrated that the impedance spectrum of plant tissues can be achieved using the development and application of an electrical impedance measurement system for plant tissues, but stated that other environmental factors should be included in the measuring system, such as temperature, humidity and irradiance.

The measured impedance spectra usually consist of not only the spectra of the tissue but also the impedance of the electrodes and the tissue between the electrodes, since the electrodes are usually punctured into the tissue, causing local damage to the cells (Zhang and Willison 1991, 1993).

In order to characterize the structural and functional changes induced by different environmental factors, one should know the impedance spectra of the normal tissue and also the parameters of the approaching model. Hayden et al. (1968), Zhang and Willison (1991), Toyoda and Tsenkova (1998) determined the normal spectra of potato and carrot. The impedance parameters of cabbage leaves were measured also by Zhang and Willison (1993) by a special, cylindrically symmetric electrode arrangement.

Most of the work done in the area of stress measurements was connected to abiotic factors (Table 7). The first plant impedance measurements were done in connection with heat stress, since food technology required quality control measurements during storage of fruits and vegetables. In potato (Hayden et al. 1968), and apple (Toyoda and Tsenkova 1998) tissues cold storage induced an increase either in the apoplast, or in the symplast as well. EIS was also successfully applied for investigations of conservation processes, such as freezing of apple slices. The modified Hayden-model can be used to follow heat denaturation of potato tissue. In the process of drying, both symplastic and apoplastic resistances decrease (Toyoda and Tsenkova 1998). The parameters of EIS are also suitable for the estimation of nutrient supply in plants. Phosphorous deficiency causes a more pronounced increase in the resistance values than potassium deficiency (Greenham et al. 1972). The effects of irradiation can also be followed by impedance parameters. Felföldi et al. (1993) observed that at $50 \mathrm{kHz}$ the ratio of the magnitude of the measured impedance grows as the irradiation time is longer when compared to the values measured at $5 \mathrm{kHz}$. Membrane injuries caused by heat (Zhang et al. 1993) and frost (Zhang and Willison 1992; Repo et al. 1994, 2000) stress have also been studied using EIS. Moreover, mechanically broken membrane structure can also be detected by changes in different EIS parameters (Cox et al. 1993; Vozáry et al. 1999).

Furthermore recently, cadmium stress and the effect of anoxia caused by flooding seemed to be detected by EIS (Jócsák et al. 2010) in the early stage of development of pea (Pisum satvium L.) seedlings. Those results showed a concentrationdependent increase of the symplastic resistance, and the energy inhibitory effect of anoxia was also possible to follow with EIS (Vozáry et al. 2011).

A Malaysian medicinal plant Labisia pumila has anticancer, antioxidant and anti-inflammatory properties. The growth and production of L. pumila is greatly influenced by the plant water status. In the study of Jamaludin et al. (2015), the plant water status was measured using EIS: a pair of electrocardiogram (ECG) electrodes connected to an impedance analyzer board was used to measure the impedance value of the leaf samples non-invasively. Evapotranspiration replacement (ER) treatment was: 100\%; well watered, $75 \%$, moderate water stress, $50 \%$; high water stress and $25 \%$; severe water stress.

The results showed that after 20 weeks of treatment, $25 \%$ ER had the highest impedance value ranged from 0.10 to $0.15 \mathrm{M} \Omega$ at the frequency of $70-100 \mathrm{kHz}$. They attributed these results to the 
Table 7 Plant stress followed by EIS

\begin{tabular}{|c|c|c|}
\hline Apple (Malus domestica L.) & Drying & Vozáry et al. (1999) \\
\hline Apple (Malus domestica L.) & Drying & Vozáry and Horváth (1998) \\
\hline Apple (Malus domestica L.) & Membrane injury & Zhang et al. (1993) \\
\hline Apple (Malus domestica L.) & Mechanically broken membrane structure & $\begin{array}{l}\text { Cox et al. (1993), Vozáry } \\
\text { et al. (1999) }\end{array}$ \\
\hline Cacip fatimah (Labisia pumila) & Water stress & Jamaludin et al. (2015) \\
\hline Pea (Pisum sativum L.) & Cadmium stress & Jócsák et al. (2010) \\
\hline Pea (Pisum sativum L.) & Anoxia & Vozáry et al. (2011) \\
\hline Haplophytic plants & Salinity stress & Hamed et al. (2016) \\
\hline $\begin{array}{l}\text { Norway pruce (Picea abies L. } \\
\text { Karst) }\end{array}$ & Snow melt-climate change & Repo et al. (2011) \\
\hline Potato (Solanum tuberosum L.) & Normalised spectra determination & Hayden et al. (1968) \\
\hline Potato (Solanum tuberosum L.) & Cold storage & $\begin{array}{l}\text { Toyoda and Tsenkova } \\
\text { (1998) }\end{array}$ \\
\hline Potato (Solanum tuberosum L.) & Heat denaturation & Toyoda et al. (1994) \\
\hline Potato (Solanum tuberosum L.) & Normalised spectra determination & Zhang and Willison (1991) \\
\hline Potato (Solanum tuberosum L.) & Irradiation & Felföldi et al. (1993) \\
\hline Potato (Solanum tuberosum L.) & Tobacco mosaic virus & Greenham et al. (1978) \\
\hline Potato (Solanum tuberosum L.) & Tomato spotted wilt & Greenham et al. (1978) \\
\hline Scots pine (Pinus sylvestris L.) & $\begin{array}{l}\text { Root colonisation by symbiotic mycorrhizal fungi (Hebeloma } \\
\text { sp. and Suillus luteus) }\end{array}$ & Repo et al. (2014) \\
\hline Spring wheat (Triticum aestivum L.) & $\begin{array}{l}\text { Alkaline stress, cadmium contamination, drought stress and } \\
\text { weed competition }\end{array}$ & Cseresnyés et al. (2018) \\
\hline $\begin{array}{l}\text { Subterranean clover (Trifolium } \\
\text { subterraneum } \text { L.) }\end{array}$ & Phosphorous and potassium deficiency & Greenham et al. (1972) \\
\hline Tobacco (Nicotiana glutinosa L.) & Tomato spotted wilt & Greenham et al. (1978) \\
\hline Tobacco (Nicotiana tabacum L.) & Tobacco mosaic virus & Greenham et al. (1978) \\
\hline
\end{tabular}

higher resistance of less-irrigated plants and proposed EIS as an in situ and simple measurement technique for plant water status measurement (Jamaludin et al. 2015).

Impedance spectroscopy can also be used to easily and quickly compare different growth conditions and different salinity treatments suggesting that EIS might be suitable for assessing non-invasively salt resistance of plants. Also, in order to separate the osmotic from the ionic phases of the early response to salt stress, which makes the method very useful to study the signalling and the short-term responses to salinity. Another application of EIS would be to find a biological method that would separate sodium from a mixture of different salts, using halophytic plants (Hamed et al. 2016).

Repo et al. (2011) studied the effects of lack of snow and its effects on the physiology of Norway pruce (Picea abies L. Karst.) needles and root biomass under natural conditions, artificially removed from snow and soil frost for a long time. The apoplastic electrical resistance of needles was higher in frost than in the other two treatments possibly due to the smaller needle cross-sectional area, although this disappeared in the growing season. The authors attributed this change to the water content of needles that was possible to detect by EIS (Repo et al. 2011).

Cseresnyés et al. (2018) used electrical impedance phase angle as an indicator of plant root stress and found that in pot experiments the measurement of the impedance phase angle in intact with the root system is a potentially useful in situ method for detecting plant responses to stresses affecting roots, such as alkaline disturbance, cadmium contamination, drought stress and weed competition. 
Greenham et al. (1978) investigated virus infection, i.e. the local necrotic effect of tobacco mosaic virus (TMV) on Nicotiana glutinosa, the systemic infection of TMV on potato tubers, the systemic infections of tomato spotted wilt (TSW) in leaves of $N$. glutinosa and systemic infections of TMV in petioles of $N$. tabacum and successfully correlated the parameters of EIS with the physiological changes caused by virus infection.

Repo et al. (2014) investigated the effect of root colonization by symbiotic mycorrhizal fungi (Hebeloma sp. and Suillus luteus) on the electrical impedance spectra of Scots pine (Pinus sylvestris L.) after a long-day and high temperature (LDHT) and short-day and low temperature conditions (SDLT) as cold acclimation simulation. The results depended upon the cold acclimation and mycorrhizal treatment. The changes of correlation coefficients $(30 \%$ for Hebeloma sp. and $39 \%$ for S. luteus in the real part and $28 \%$ and $38 \%$ in the imaginary part,) indicated physicochemical changes (e.g. ionic behaviour) in the root caused by the colonization of the fungi (Repo et al. 2014).

\section{Conclusion}

The state of literature reveals that EIS is fairly widely applied in plant, crop and food sciences besides biomedical diagnostics.

This method is mainly useful to characterize quantitative cellular changes. Electrical impedance of tissues provides information about the cellular structure and moisture content, the characteristics and integrity of plasma membranes, intra- and extracellular parts of plant tissues. In vivo, in vitro and in situ measurements are possible with EIS and the noninvasive feature of this technique is valid for all types of investigations, not to mention the importance of the fact that it requires short time compared to other classical plant physiological measurements that involve grinding and processing of plant tissue. Furthermore, electrical impedance measurement can be done on relatively young seedlings, so the effects of stress agents can be detected even in early stages of the development, when for instance the fluorescence induction measurement, which is otherwise a highly sensitive environmental stress detecting method, cannot be done, because of the lack of fully opened leaves.
Significant stress agents such as water extremes, salinity, heavy metal stress and infection lead to structural modifications of the tissue and justify the applications of non-invasive EIS measurement for predicting plant health or characterizing greenhouse or field water conditions and usage.

EIS seems to be applicable both for analytical and research laboratories, since once a stress or a quality trait is correlated with an impedance parameter, the method is quick and safe for further analysis of a great number of samples.

Author contributions IJ collected the articles and wrote the review, GV suggested structural modifications in the review, especially for the plant-related applications. EV revised and completed the article list of the review with suggestions of articles. All authors read and approved the final manuscript."

Funding This work was supported by project EFOP-3.6.3VEKOP-16-2017-00005" co-funded from EU sources and European Structural and Investment Funds and the Hungarian State. Open access funding provided by Kaposvár University (KE).

\section{Compliance with ethical standards}

Conflict of interest The authors declare that they have no competing interest.

Open Access This article is distributed under the terms of the Creative Commons Attribution 4.0 International License (http:// creativecommons.org/licenses/by/4.0/), which permits unrestricted use, distribution, and reproduction in any medium, provided you give appropriate credit to the original author(s) and the source, provide a link to the Creative Commons license, and indicate if changes were made.

\section{References}

Ando Y, Mizutani K, Wakatsuki N (2014) Electrical impedance analysis of potato tissues during drying. J Food Eng 121:24-31. https://doi.org/10.1016/j.jfoodeng.2013.08. 008

Ando Y, Maeda Y, Mizutani K, Naoto Wakatsuki, Hagiwara S, Nabetani H (2016) Impact of blanching and freeze-thaw pretreatment on drying rate of carrot roots in relation to changes in cell membrane function and cell wall structure. LWT-Food Sci Technol 71:40-46. https://doi.org/10.1016/ j.lwt.2016.03.019

Anisko T, Lindstrom OM (1995) Applying the Richards function in freezing tolerance determination with electrolyte and phenolic leakage techniques. Phys Plant 95:281-287. https://doi.org/10.1111/j.1399-3054.1995.tb00839.x 
Arnon DI (1949) Copper enzymes in isolated chloroplasts polyphenoloxidase in beta vulgaris. Plant Phys 24:1-15. https://doi.org/10.1104/pp.24.1.1

Bai SJ, Prinz FB (2011) In vivo electrochemical impedance measurement on single cell membrane. Microelectron Eng 88:3094-3100. https://doi.org/10.1016/j.mee.2011.06.003

Bera TK, Berab S, Kar K, Mondal S (2016) Studying the variations of complex electrical bio-impedance of plant tissues during boiling. Proc Technol 23:248-255. https://doi.org/ 10.1016/j.protcy.2016.03.024

Chalermchat Y, Malangone L, Dejmek P (2010) Electropermeabilization of apple tissue: effect of cell size, cell size distribution and cell orientation. Biosyst Eng 105:357-366. https://doi.org/10.1016/j.biosystemseng.2009.12.006

Chalker-Scott L, Fuchigami LH, Harber RM (1989) Spectrophoto-metric measurements of leached phenolic compounds as an indicator of freeze damage. J Am Soc Hortic Sci 114:315-319

Chloupek O (1977) Evaluation of the size of a plants root system using its electrical capacitance. Plant Soil 48:525-532. https://doi.org/10.1007/BF02187258

Cox MA, Zhang MIN, Willison JHM (1993) Apple bruise assessment through electrical impedance measurements. J Hortic Sci 68:393-398. https://doi.org/10.1080/ 00221589.1993.11516366

Cseresnyés I, Rajkai K, Takács T, Vozáry E (2018) Electrical impedance phase angle as an indicator of plant root stress. Biosyst Eng 169:226-232. https://doi.org/10.1016/j. biosystemseng.2018.03.004

Dalton FN (1995) In-situ root extent measurements by electrical capacitance methods. Plant Soil 173:157-165. https://doi. org/10.1007/BF00155527

Dean DA, Ramanathan T, Machado D, Sundararajan R (2008) Electrical impedance spectroscopy study of biological tissues. J Electrostat 66:165-177. https://doi.org/10.1016/j. elstat.2007.11.005

Euring F, Russ W, Wilke W, Grupa U (2011) Development of an impedance measurement system for the detection of decay of apples. Proc Food Sci 1:1188-1194. https://doi.org/10. 1016/j.profoo.2011.09.177

Felföldi J, László P, Barabássy S, Farkas J (1993) Dielectric method for detection of irradiation treatment of potatoes. Radiat Phys Chem 41:471-480. https://doi.org/10.1016/ 0969-806X(93)90007-H

Fuentes A, Vázquez-Gutiérrez JL, Pérez-Gago MB, Vonasek E, Nitin N, Barrett DM (2014) Application of nondestructive impedance spectroscopy to determination of the effect of temperature on potato microstructure and texture. J Food Eng 133:16-22. https://doi.org/10.1016/j.jfoodeng.2014. 02.016

Greenham CG, Randall JP, Ward MM (1972) Impedance parameters in relation to phosphorus and calcium deficiencies in subterranean clover (Trifolium subterraneum L.). J Exp Bot 23:197-209. https://doi.org/10.1093/jxb/23. 1.197

Greenham CG, Helms K, Müller WJ (1978) Influence of virus inflections on impedance parameters. $\mathrm{J}$ Exp Bot 29(4):867-877. https://doi.org/10.1093/jxb/29.4.867

Grimnes S, Martinsen OG (2000) Electrical properties of tissue. Bioimpedance \& bioelectricity basics. Wiley, New York
Guo WC, Nelson SO, Trabelsi S, Kays SJ (2007) Dielectric properties of honeydew melons and correlation with quality. J Microw Power Electromagn Energy 41:48-58. https://doi.org/10.1080/08327823.2006.11688556

Hagrey SA (2007) Geophysical imaging of root-zone, trunk and moisture heterogenity. J Exp Bot 58:839-854. https://doi. org/10.1093/jxb/erl237

Halter R, Hartov A, Heaney J, Paulsen K, Schned A (2007) Electrical impedance spectroscopy of the human prostate. IEEE Trans Biomed Eng 54(7):1321-1327. https://doi.org/ 10.1109/TBME.2007.897331

Halter RJ, Schned A, Heaney J, Hartov A, Schutz S, Paulsen KD (2008) Electrical impedance spectroscopy of benign and malignant prostatic tissues. J Urol 179:1580-1586. https:// doi.org/10.1016/j.juro.2007.11.043

Hamed KB, Zorrig W, Hamzaoui AH (2016) Electrical impedance spectroscopy: a tool to investigate the responses of one halophyte to different growth and stress conditions. Comput Electron Agric 123:376-383. https://doi.org/10. 1016/j.compag.2016.03.006

Harker FR, Maindonald JH (1994) Changes in cell wall, vacuole, and membranes detected using electrical impedance measurements. Plant Phys 106:165-171. https://doi.org/ 10.1104/pp.106.1.165

Hayden RI, Moyse CA, Cadler FW, Crawford DP, Fensom DS (1968) Electrical impedance studies on potato and alfalfa tissue. J Exp Bot 20:177-200

Hietala T, Hiekkala P, Rosenqvist H, Laakso S, Tahvanainen L, Repo T (1998) Fatty acid and alkane changes in willow during frost-hardening. Phytochemistry 47:1505-1507. https://doi.org/10.1016/S0031-9422(97)01083-2

Imaizumi T, Tanaka F, Hamanaka D, Sato Y, Uchino T (2015) Effects of hot water treatment on electrical properties, cell membrane structure and texture of potato tubers. J Food Eng 162:56-62. https://doi.org/10.1016/j.jfoodeng.2015. 04.003

Jamaludin D, Aziz SA, Ahmad D, Jaafar HZE (2015) Impedance analysis of Labisia pumila plant water status. Inf Proc Agric 2:161-168. https://doi.org/10.1016/j.inpa.2015. 07.004

Jinyang L, Meiqing L, Hanping M, Wenjing Z (2016) Diagnosis of potassium nutrition level in Solanum lycopersicum based on electrical impedance. Biosyst Eng 147:130-138. https://doi.org/10.1016/j.inpa.2015.07.004

Jócsák I, Villányi V, Gy Rabnecz, Droppa M (2008) Investigation of nickel stress induction in terms of metal accumulation and antioxidative enzyme activity in barley seedlings. Acta Biol Szegediensis 52:167-171

Jócsák I, Droppa M, Horváth G, Bóka K, Vozáry E (2010) Detection of the effect of cadmium and flooding induced anoxia stresses by electrical impedance measurement in pea (Pisum sativum L.) roots. Zeitschrift für Naturforsch C 65:95-102. https://doi.org/10.1515/znc-2010-1-216

Karásková P, Fuentes A, Fernández-Segovia I, Alcañiz M, Masot R, Barat JM (2011) Development of a low-cost nondestructive system for measuring moisture and salt content in smoked fish products. Proc Food Sci 1:1195-1201. https://doi.org/10.1016/j.profoo.2011.09.178

Kuang W, Nelson S (1998) Low-frequency dielectric properties of biological tissues. A review with some new insights. 
Trans ASAE 41(1):173-184. https://doi.org/10.13031/ 2013.17142

Kuo YF, Su YZ, Tseng YH, Wang SY, Wang HM, Chueh PJ, Flavokawain B (2010) A novel chalcone from Alpinia pricei Hayata with potent apoptotic activity: involvement of ROS and GADD153 upstream of mitochondria-dependent apoptosis in HCT116 cells. Free Radic Biol Med 49:214-226. https://doi.org/10.1016/j.freeradbiomed. 2010.04.005

Kuson P, Terdwongworakul A (2013) Minimally-destructive evaluation of durian maturity based on electrical impedance measurement. J Food Eng 116:50-56. https://doi. org/10.1016/j.jfoodeng.2012.11.021

Lichtenthaler HK (1996) Vegetation stress. An introduction to the stress concept to plants. J Plant Phys 148:4-14. https:// doi.org/10.1111/j.1749-6632.1998.tb08993.x

Lin CM, Chen LH, Chen TM (2012) The development and application of an electrical impedance spectroscopy measurement system for plant tissues. Comput Electron Agric 82:96-99. https://doi.org/10.1016/j.compag.2011.10.017

Liua JT, Settub K, Tsaib JZ, Chenc CJ (2015) Impedance sensor for rapid enumeration of $E$. coli in milk samples. Electrochim Acta 182:89-95. https://doi.org/10.1016/j. electacta.2015.09.029

Lougheed EC, Miller SR, Ripley BD, Cline RA (1981) Electrical impedance of damizonide- and calcium-treated McIntosh apples. Experientia 37:835-836. https://doi.org/ 10.1007/BF01985666

Luoranen J, Repo T, Lappi J (2004) Assessment of the frost hardiness of shoots of silver birch (Betula pendula) seedlings with and without controlled exposure to freezing. Can J Fish Res 34:1108-1118. https://doi.org/10.1139/x03-285

MacDonald JR (1992) Impedance spectroscopy. Ann Biomed Eng 20:289-305. https://doi.org/10.1007/BF02368532

Martinsen OG, Grimnes S, Schwan HP (2002) Interface phenomena and dielectric properties of biological tissue. In: Encyclopedia of surface and colloid sci. Marcel Dekker, New York, pp 2643-2652

McRae D, Esrick M, Mueller S (1999) Changes in the noninvasive, in vivo electrical impedance of three xenografts during the necrotic cell-response sequence. Int J Radiat Oncol 43:849-857. https://doi.org/10.1016/S03603016(98)00487-8

Meiqing L, Jinyang L, Hanping M, Yanyou W (2016) Diagnosis and detection of phosphorus nutrition level for Solanum lycopersicum based on electrical impedance spectroscopy. Biosyst Eng 143:108-118. https://doi.org/10.1016/j. biosystemseng.2016.01.005

Micskei, Gy, Jócsák I, Árendás T, Bónis P, Berzsenyi Z (2009) Effect of farmyard manure and mineral fertiliser on the yield and yield components of maize in monoculture longterm experiment in Martonvásár. Tartamkísérletek jelentősége a növénytermesztés fejlesztésében 127-132

Nadezhdina N, Čermák J (2003) Instrumental methods for studies of structure and function of root systems of large trees. J Exp Bot 54:1511-1521. https://doi.org/10.1093/ jxb/erg 154

Nakonieczna A, Paszkowski B, Wilczek A, Szypłowska A, Skierucha W (2016) Electrical impedance measurements for detecting artificial chemical additives in liquid food products. Food Control 66:116-129. https://doi.org/10. 1016/j.foodcont.2016.01.044

Nelson SO (2005) Dielectric spectroscopy of fresh fruit and vegetable tissues from 10 to $1800 \mathrm{MHz}$. J Microw Power Electromagn Energy 40:31-47. https://doi.org/10.1080/ 08327823.2005.11688520

Panissod C, Michot D, Benderitter Y, Tabbagh A (2001) On the effectiveness of $2 \mathrm{D}$ electrical inversion results. An agricultural case study. Geophys Prospect 49:570-576. https:// doi.org/10.1046/j.1365-2478.2001.00277.x

Paredes J, Becerro S, Arana S (2014) Comparison of real time impedance monitoring of bacterial biofilmcultures in different experimental setups mimicking real field environments. Sens Actuators, B 195:667-676. https://doi.org/10. 1016/j.snb.2014.01.098

Pething R, Kell DB (1987) The passive electrical properties of biological systems. Their significance in physics, biophysics and biotechnology. Phys Med Biol 32:933-970. https://doi.org/10.1088/0031-9155/32/8/001

Privé JP, Zhang MIN (1996) Estimating cold stress in 'Beautiful arcade' apple roots using electrical impedance analysis. HortTechnology 6:54-58

Rajkai K, Végh KR, Nacsa T (2002) Electrical capacitance as the indicator of root size and activity. Agrokémia és Talajtan 51:1-10. https://doi.org/10.1556/Agrokem.51. 2002.1-2.11

Rajkai K, Kr Végh, Nacsa T (2005) Electrical capacitance of roots in relation to plant electrodes, measuring frequency and root media. Acta Agron Hung 53:197-210. https://doi. org/10.1556/AAgr.53.2005.2.8

Repo T (1994) Influence of different electrodes and tissues on the impedance spectra of Scots pine shoots. ElectroMagnetobiol 13:1-14. https://doi.org/10.3109/ 15368379409030694

Repo T, Pulli S (1996) Application of impedance spectroscopy for selecting frost hardy varieties of English ryegrass. Ann Bot 78:605-609. https://doi.org/10.1006/anbo.1996.0167

Repo T, Zhang MIN (1993) Modelling woody plant tissues using a distributed electrical circuit. J Exp Bot 44:977-982. https://doi.org/10.1093/jxb/44.5.977

Repo T, Zhang MIN, Ryyppo A, Vapaavuori E, Sutinen S (1994) Effects of freeze-thaw injury on parameters of distributed electrical circuits of stems and needles of Scots pine seedlings at different stages of acclimation. J Exp Bot 45:823-833. https://doi.org/10.1093/jxb/44.5.977

Repo T, Hiekkala P, Hietala T, Tahvanainen L (1997) Intracellular resistance correlates with frost hardening in willow (Salix viminalis). Phys Plant 101:627-634. https://doi.org/ 10.1111/j.1399-3054.1997.tb01047.x

Repo T, Zhang G, Ryyppo A, Rikala R (2000) The electrical impedance spectroscopy of Scot pine (Pinus sylvestris L.) shoots in relation to cold acclimation. J Exp Bot 51:2095-2107. https://doi.org/10.1093/jexbot/51.353. 2095

Repo T, Laukkanen J, Silvennoinen R (2005) Measurement of the tree root growth using electrical impedance spectroscopy. Silva Fennica 39:159-166. https://doi.org/10. 14214/sf.380

Repo T, Lehto T, Finér L (2008) Delayed soil thawing affects root and shoot functioning and growth in Scots pine. Tree Phys 10:1583-1591 
Repo T, Roitto M, Sutinen S (2011) Does the removal of snowpack and the consequent changes in soil frost affect the physiology of Norway spruce needles? Environ Exp Bot 72:387-396. https://doi.org/10.1016/j.envexpbot. 2011.04.014

Repo T, Korhonen A, Laukkanen M, Lehto T, Silvennoinen R (2014) Detecting mycorrhizal colonisation in Scots pine roots using electrical impedance spectra. Biosyst Eng 121:139-149. https://doi.org/10.1016/j.biosystemseng. 2014.02.014

Scandurra G, Tripodi G, Verzera A (2013) Impedance spectroscopy for rapid determination of honey floral origin. J Food Eng 119:738-743. https://doi.org/10.1016/j. jfoodeng.2013.06.042

Shabala L, Ross T, McMeekin T, Shabala S (2006) Non-invasive microelectrode ion flux measurements to study adaptive responses of microorganisms to the environment. FEMS Microbiol Rev 30:472-486. https://doi.org/10. 1111/j.1574-6976.2006.00019.x

Soley A, Lecina M, Gamez X, Cairo JJ, Riu P, Rosell X, Bragos R, Godia F (2005) On-line monitoring of yeast cell growth by impedance spectroscopy. J Biotechnol 118:398-405. https://doi.org/10.1016/j.jbiotec.2005.05.022

Sotoyama H, Saito M, Oh K, Nemoto Y, Matsuoka H (1998) In vivo measurement of the electrical impedance of cell membranes of tobacco cultured cells with a multifunctional microelectrode system. Bioelectrochem Bioenerg 45:83-91. https://doi.org/10.1016/S0302-4598(97)000810

Stout DG (1988a) Effect of cold acclimation on bulk tissue electrical impedance. I. Measurements with birdsfoot trefoil at subfreezing temperatures. Plant Phys 86:275-282

Stout DG (1988b) Effect of cold acclimation on bulk tissue electrical impedance. II. Measurements with alfalfa and birdsfoot trefoil at nonfreezing temperatures. Plant Phys 86:283-287

Sugiyama J, Hayashi T, Horiuchi H (1989) Changes in electrical impedance of prince melon during ripening. Nippon Shokuhin Kogyo Gakkaishi 36:424-427. https://doi.org/10. 3136/nskkk1962.36.5_424

Sutinen LM, Palta JP, Reich PB (1992) Seasonal differences in freezing stress resistance of needles of Pinus nigra and Pinus resinosa. Evaluation of the electrolyte leakage method. Tree Phys 11:241-254

Szigeti Z, Richter P, Lichtenthaler HK (1996) Fluorescence emission spectra of paraquat resistant Conyza canadensis during the chlorophyll fluorescence induction as determined by the CCD-OMA system. J Plant Phys 148:574-578. https://doi.org/10.1016/S01761617(96)80077-0

Takacs Z, Lichtenthaler HK, Tuba Z (2000) Fluorescence emission spectra of desiccation-tolerant cryptogamic plants during a rehydration-desiccation cycle. J Plant Phys 156:375-379. https://doi.org/10.1016/S01761617(00)80076-0

Toyoda K, Tsenkova R (1998) Measurements of freezing process of agricultural products by impedance spectroscopy. In: 2nd international workshop on control application in post-harvest and processing technology, Budapest

Toyoda K, Farkas I, Kojima H (1994) Monitoring changes in material properties of agricultural products during heating and drying by impedance spectroscopial analysis. J Food Phys 2:69-98

Tuba Z, Csintalan Z, Badacsonyi A, McF Proctor (1997) Chlorophyll fluorescence as an exploratory tool for ecophysiological studies on mosses and other small poikilohydric plants. J Bryol 19:401-407. https://doi.org/10.1179/ jbr.1997.19.3.401

Väinölä A, Repo T (2000) Impedance spectroscopy in frost hardiness evaluation of Rhododenron leaves. Ann Bot 86:799-805. https://doi.org/10.1006/anbo.2000.1237

Vozáry E, Horváth D (1998) Change in impedance parameters of apple slices during drying process. IFAC Proc 31:123-125. https://doi.org/10.1016/S14746670(17)44042-0

Vozáry E, László P, Sass P (1997) Effects of storage on electrical impedance of apple tissues. In: 2nd European biophysics congress, Orléans, 13-17 July 1997

Vozáry E, László P, Zsivanovits G (1999) Impedance parameter characterizing apple Bruise. Ann N Y Acad Sci 873:421-429. https://doi.org/10.1111/j.1749-6632.1999. tb09491.x

Vozáry E, Jócsák I, Droppa M, Bóka K (2011) Connection between structural changes and electrical parameters of pea root tissue under Anoxia. In: Padilla PA (ed) InTech Open Access Publisher, pp 131-146

Wang RY, Zhang T, Bao Q, Rawson DM (2005) Study on fish embryo responses to the treatment of cryoprotective chemicals using impedance spectroscopy. Eur Biophys J 35:224-230. https://doi.org/10.1007/s00249-005-0027-5

Weaver GM, Jackson HO (1966) Electrical impedance, an objective index of maturity in peach. Can J Plant Sci 46:323-326. https://doi.org/10.1016/09255214(94)90014-0

Wei YQ, Bailey BJ, Stenning BC (1995) A wetness sensor for detecting condensation on tomato plants in greenhouses. J Agric Eng Res 61:197-204. https://doi.org/10.1006/jaer. 1995.1047

Xu Y, Xie X, Duan Y, Wang L, Cheng Z, Cheng J (2016) A review of impedance measurements of whole cells. Biosens Bioelectron 77:824-836. https://doi.org/10.1016/j. bios.2015.10.027

Yang L (2008) Electrical impedance spectroscopy for detection of bacterial cells in suspensions using interdigitated microelectrodes. Talanta 74:1621-1629. https://doi.org/ 10.1016/j.talanta.2007.10.018

Yoshida S (1984) Chemical and biophysical changes in the plasma membrane during cold acclimation of mulberry bark cells (Morus bombycis Koidz. Cv Goroji). Plant Phys 76:257-265. https://doi.org/10.1104/pp.76.1.257

Zhang MIN, Willison JHM (1991) Electrical impedance analysis in plant tissues. A double shell model. J Exp Bot 42:1465-1476. https://doi.org/10.1093/jxb/42.11.1465

Zhang MIN, Willison JHM (1992) Electrical impedance analysis in plant tissues. The effect of freeze-thaw injury on the electrical properties of potato tuber and carrot root tissues. Can J Plant Sci 72:545-553. https://doi.org/10.1093/jxb/ 41.3.371

Zhang MIN, Willison JHM (1993) Electrical impedance analysis in plant tissue: impedance measurement in leaves. J Exp Bot 44:1369-1375. https://doi.org/10.1093/jxb/42. 11.1465 
Zhang MIN, Willison JHM, Cox MA, Hall SA (1993) Measurements of heat injury in plant tissue by using electrical impedance analysis. Can J Bot 71:1605-1611. https://doi. org/10.1139/b93-195

Zheng L, Wang L, Sun H, Zhang M, Li M (2015) Real-time evaluation of corn leaf water content based on the electrical property of leaf. Comput Electron Agric 112:102-109. https://doi.org/10.1016/j.compag.2014.11.007

Zou Y, Guo Z (2003) A review of electrical impedance techniques for breast cancer detection. Med Eng Phys
25:79-90. https://doi.org/10.1016/S1350-4533(02)001947

Żywica R, Banach JK (2015) Simple linear correlation between concentration and electrical properties of apple juice. J Food Eng 158:8-12. https://doi.org/10.1016/j.jfoodeng. 2015.02.012

Publisher's Note Springer Nature remains neutral with regard to jurisdictional claims in published maps and institutional affiliations. 